\title{
Towards Sustainable Production: The Case of the Manufacturing Industry in Colombia and México*
}

\author{
Mariana Hernández González ${ }^{1}$, Patricia Jissette Rodríguez Sánchez ${ }^{2}$
}

\begin{abstract}
The United Nations' agenda for sustainable development highlights the need to create resilient infrastructures for a sustainable industry that fosters innovation, while increasing resource utilization at all levels of the supply chain, from production to the final consumer. This research aims to expose the strategies that the manufacturing industry undertook towards sustainable development in Colombia and Mexico between 2010 and 2016, in which the documentary research methodology with a qualitative approach was utilized, supported by specialized academic journals. As a result, the countries' efforts can be analyzed in 3 categories: the development of new products, the use of new sources of energy such as renewables, and the construction of a green market around one true sustainable production.
\end{abstract}

Keywords: Sustainable production, green market, renewable energy, sustainable development.

\section{Introduction}

The countries' commitment to the environment and sustainability goes beyond compliance with the Sustainable Development Goals, as it is a commitment to society and future generations. Thus, it is important to identify what activities, strategies, and policies are implemented in both Colombia and Mexico, from one of the most important sectors in these economies, such as manufacturing, between 2010 and 2016. It is specifically important to analyze these strategies from three perspectives: the development of new products, the conformation of green markets, and the implementation and use of renewable energies.

The process of industrialization has a transformative impact on society and the environment. Although there are important differences in the form and speed with which each nation carries this process, the transition from manual and individual work to mass production within organizations brings advantages such as socio-economic reactivation, technological development, and improvements within the quality of life of the population. However, it also has negative repercussions, such as pollution, the abuse of natural resources, and inequality in the population.

Conversely, the consumer is also changing. At the local level, consumer habits are enforcing the importance of the companies' impacts on their lifestyle, community, and the environment. Consumers are demanding greater transparency and clarity of their manufacturing processes and origins of their raw materials, recognizing these practices may question ecological, ethical, and humanistic practices (Villegas, 2013). This situation forces manufacturers to rethink how these processes are implemented

\footnotetext{
${ }^{1}$ Dept. of Systems, Universidad Autónoma Metropolitana, Azcapotzalco, Mexico

${ }^{2}$ Faculty of Distance Studies, Universidad Militar Nueva Granada, Colombia; Corresponding Author

* Result of the project INV-DIS-2576, financed by the Research Vice-Rectory of the Universidad Militar

Nueva Granada. Validity 2018.
} 
In Mexico, the manufacturing sector is one of the greatest contributors to economic growth in terms of the main macroeconomic variables. In Colombia, the manufacturing sector is the fourth largest sector of the country's Gross Domestic Product (after financial establishments, personal activities and trade) and is the second largest recipient of foreign investment in the country at 30\%, after mining and energy activity with 39\% (Banco de la República, 2015a). The Colombian economy has suffered a large deindustrialization due to the economic opening in 1990, although it continues a slight growth in average. Its share of Gross Domestic Product (GDP) has fallen continuously, from $19.2 \%$ in 1990 to $13.9 \%$ in 2000 and only $11.4 \%$ in 2016.

In environmental terms, the process of transforming resources implies leaving an environmental footprint. Thus, the current productive model increases this footprint by exceeding the environmental capacity to regenerate as it causes waste that contaminates water, air, and soil, makes excessive use of natural resources, and consumes large amounts of electrical energy. As a result, the deterioration of the quality of water resources in Colombia is highlighted, largely due to the organic matter generated by industrial activities. In 2008, the organic matter produced was equivalent to the load generated by 17.5 million inhabitants (Valencia, Suárez Castaño, Sánchez, Cardozo, \& Bonilla, 2010).

Given the need to make a technological change in the form of production applied to the different industries that make up the manufacturing sector, challenges are presented at different levels. For example, at the national level, work is focused on legislation and normativity that generates the technological transition aimed caring for the environment and reducing the environmental footprint, as well as establishing institutions responsible for environmental monitoring, evaluation and sanction.

This paper aims to highlight the challenges at the sectoral level, which implies a change in traditional production methods under the commitment to reduce emissions of polluting gases, improve solid waste management, and optimize energy needs and attention to the needs and preferences of the consumer.

\subsection{Main conceptual review}

This section presents the main concepts used in the analysis of this paper.

\subsubsection{Sustainable production}

It can be defined as the industrial activity that allows the transformation of raw materials into products with higher value added, but using processes that minimize negative impacts on the environment, reducing energy consumption and natural resources, and being safe for employees, communities and consumers while remaining economically viable (OECD, 2009). Sustainable production includes the conversion of productive processes, the substitution of raw materials for sustainable ones, strategies for the reduction of energy consumption and water resources, as well as the cleaning, treatment and management of polluting waste emitted into the environment.

\subsubsection{Green market}

The concept of green market encompasses both elements of the market, the characteristics and practices of the producer, who shapes the industry, and on the other 
hand, the consumer with specific preferences. The concept refers to the set of products that count with particular characteristics such as being environmentally friendly, allowing the use of local resources, manufacturing with less contaminants and counting on technologies that minimize impact on water, soil and air (González, 2011). At the same time, the green market responds to a consumer who is informed and concerned about the quality and social responsibility of the companies that supply him/her. This is an individual whose purchasing decision is affected by aspects that are not related to the functionality of the product, considers the ecological impact, equity, and political and cultural dimensions that allow him/her to reduce the impact of his/her consumption (UNESCO, s.f.).

This concept is used to generate a differentiation of both product and image of the company. For this reason, the green market is constantly related to concepts such as social responsibility and fair trade, which in turn are part of sustainable consumption. From the researcher's point of view, the green market is largely explained by consumers' demand for sustainable products, so its development is closely related to the type of consumer in the region.

\subsubsection{Renewable energy}

Renewable energies come from natural and inexhaustible sources that present themselves as substitutes for energy derived from fossil fuels. Although they can be transformed into any type of energy, technological developments are oriented to their conversion into electric energy, which allows replacing the traditional thermal method that generates high $\mathrm{CO} 2$ emissions and requires non-renewable fuels. The most prominent investments in renewable energies are carried out by the government in order to reduce their dependence on oil and its derivatives, while simultaneously reducing their emissions of greenhouse gases. However, there are also companies interested in providing and utilizing this type of technology. Although the energy sector differs from the manufacturing sector, this paper refers to the development of new methods for the generation of renewable energy, as well as studies related to its efficiency and economic feasibility.

\section{Methodology}

This paper illustrates the results of a documentary review of articles, publications in indexed journals from Latin America, official documents and research on strategies, as well as technologies and projects that are undertaken to contribute to sustainable development from the manufacturing industry in Colombia and Mexico. Documents between the years of 2010 and 2016 were selected.

Advanced searches were conducted on EBSCO, Engeneering Village, ScienceDirect, Scopus, Proquest databases using the search terms "sustainable production," "green market," and "renewable energy" in both Spanish and English. The search was limited in areas of business, management and accounting, energy, engineering, and environmental science, where it also contained the words "Colombia" or "Mexico" in abstract, title or keywords, which yielded a total of only 341 documents. After reviewing one by one, the total documents that matched the objective of this research was 78 (see table 1). 
Table 1. Number of documents selected per Database

\begin{tabular}{lcccccc}
\hline Database/Keywords & EBSCO & Engeneering Village & Science-Direct & Scopus & Proquest & Others \\
\hline Sustainable production & 3 & 4 & 7 & 3 & 3 & 8 \\
Green market & 0 & 1 & 3 & 3 & 2 & 6 \\
Renewable energy & 6 & 7 & 1 & 0 & 7 & 14 \\
\hline
\end{tabular}

The keywords used in the search encompassed the three dimensions of sustainable development while maintaining the established boundary: the study of the manufacturing sector. This precision is necessary since a large proportion of documents were found related to the key concepts, but that dealt with cases framed in the performance of the primary sector or services.

\section{Comparative Results in Colombia and Mexico}

\subsection{Sustainable Production}

The findings on Colombia and its production processes show that the country is not as sustainable as expected under the Sustainable Development Goals. Colombia as well as the Latin American region are characterized by development based on the export of primary resources and the importation of industrial goods and technology, with a rapid growth in the consumption of raw materials. This is not reflected in national income that makes it less efficient. Population growth with increased per capita income have increased the consumption of materials, while technological change does not contribute to the moderation of consumption (West and Schandl, 2013).

The trends in resource efficiency revealed in this study suggest that securing a prosperous and sustainable future for Latin America over the long term will require that the individual nations develop their capacity to use natural resources more efficiently, extracting more value per unit of resources used. Moving more of the region's productive activities further up the value adding chain from the commodities initially extracted would achieve this (West y Schandl, 2013, p. 25).

The sustainable production research is grouped into products, services and processes that are created for sustainability by the companies. The papers on sustainable production in Colombia analyzed, for the most part, simulations of different "energy mix" for the use of renewable energies; however this aspect will be analyzed later.

In particular, we found the use of alkaline activation technology for the production of high performance concrete based on industrial byproducts, which benefits different civil infrastructure applications through the use of environmentally friendly construction materials (Bernal, Mejía de Gutiérrez, and Rodríguez, 2013).

The situation in Mexico is similar; despite having a more developed manufacturing sector, there is a high reluctance to modify production processes in favor of sustainability. Some case studies conducted in cities oriented to the manufacturing industry (Navarrete, 2015 and Santos 2010) indicate the low interest of entrepreneurs to adopt sustainable practices that do not imply a rapid recovery of investment or that are due to compliance with some regulations.

Despite the above, there are efforts made by research centers to generate proposals that offer sustainable alternatives to the private initiative. These efforts are directed in two 
lines, the first and most abundant is the analysis of new materials that meet the same characteristics of the usual raw materials, but have a lower impact on the environment during their extraction process. This lesser impact is either because they are considered a waste of a different production process, such as the surplus in the avocado plantation (Fuentes-Talavera, et al, 2011), the sugarcane bagasse (Vargas-Radillo, et al, 2015), the PET used in the manufacture of packaging (Jaramillo, et al., 2014) or the vegetables waste from markets (Mantilla, et al, 2010). In this type of research, we have detected compatibilities between the physicochemical characteristics of the materials that would allow them to be used in specific products such as the construction of light structures, the production of paper pulp or biofertilizers.

In another sense, the researchers are also focused on the evaluation of materials that can be obtained in the locality. This is intended to diminish the environmental impact by stimulating the development of the community and avoiding long shipments of materials that in some cases are highly demanded, e.g. the research carried out by Quitanar (2012) and De la Paz (2016), who independently analyze the feasibility of replacing the wood used in the local industries with an endemic species whose industrial use has not been exploited.

Finally, it should be noted that no studies were found that contribute to the implementation of these new materials or technologies in particular industries, which would make a valuable contribution to industrial reconversion.

\subsection{Green market}

The information published about Colombia on green markets is rather scarce; there are no studies in recent years on the behavior of the supply and demand of sustainable goods and services, however, it is possible that the companies focused on disseminating the results as technical results or social and environmental responsibility (environmental awareness), rather than as a topic of marketing or branding.

In Colombia, there is the "National Strategic Plan for Green Markets" of the Ministry of Environment, Housing and Territorial Development, in 2002, which categorizes green markets in: 1. Clean Development Mechanism, which seeks to reduce and capture Greenhouse gases; 2. Sustainable use of natural resources and biodiversity: (Natural timber and non-timber products, organic farming, biotechnology); 3. Industrial Ecoproducts, such as cleaner manufactured products, clean technologies, clean energy, waste management and recycling, sustainable mining; and 4. Environmental services (Subgerencia Cultural del Banco de la República, 2015). The plan sought to boost the demand for green products, but, no studies have been found to identify whether consumer behavior and preferences are geared towards finding products with a lower environmental impact.

From the point of view of supply, companies that carry out activities related to sustainability have an unexplored field of action in communicating their activities and environmental results, as a tool for corporate social responsibility, ecological marketing and branding, which can be an opportunity for market positioning. "Sustainability is increasingly viewed as a quality attribute, enabling firms to garner price premiums from the market" (Crowder and Reganold, 2015); yet, studies carried out by Chacón Páez, Pinzón Vargas, Ortegón Cortázar, \& Rojas Berrio (2016) into 36 leading Colombian 
companies that carried out voluntary practices around the Carbon Footprint (HdC) for the reduction of greenhouse gases (GEI), found that future projects are not intended to communicate their environmental activities or results as a market positioning strategy, but there is an environmental commitment and the purpose of assessing their impact, in line with the millennium goals.

Companies do not communicate through changes in their packaging, slogans, or in their corporate image. There are no detailed studies or advertise HdC (or sustainability) campaigns, although they focus on participating and sponsoring environmental responsibility campaigns, obtaining certifications such as Green stamp for marketing purposes and access to international markets (Chacón Páez, et al, 2016).

Nonetheless, the lack of communication between companies and consumers presents a disadvantage in environmental behavior. In accordance with Carrete, Castaño, Felix, Centeno, \& González (2012) there is a lack of knowledge and education about environmental issues. Even the more educated informants in their study had doubts about environmentally-friendly behavior or what the terminology "green products" really means.

In some cases, respondents claimed outright that companies and the media intentionally misinform consumers and lie about the implications and benefits of eco-friendly products. It seems that media communication from private and public organizations have not contributed substantially to the increase in consumers' knowledge on environmental matters (Carrete, et al, 2012, p.477)

In the case of Mexico, the green market is also poorly developed. It is the large companies or those oriented abroad that are most interested in joining the market (Saavedra, 2011). Some studies have been constructed to evaluate the response of consumers to different companies, considering their productive processes, their gender perspective, contribution to community development and protection of the environment (Méndez, \& Peralta, 2014; Gómez \& Berlanga 2013; Koellner, Ojeda \& Arredondo, 2016).

The studies have been applied in different regions of the country but agree on some important conclusions: usually all of the companies that perform some sustainable practice, mainly those that contribute to the development of the community, are interested in using it as a competitive advantage. In other words, the extent to which the implementation of different sustainable actions can directly depend on how useful it is to disseminate their results to improve their image, however, no studies were found that could determine the impact of these social and corporate responsibility practices on consumer buying decision. Only Arredondo, et al. (2011) conducts a field study in the north of the country in order to determine if there is a correlation between the image of the company, in terms of its social responsibility, and the purchase decision, classifying the buyer according to age and gender. The study shows that it is adult women who demand sustainable products, consume products responsibly, and are more motivated to punish a company whose practices are considered harmful to humans and the environment.

Regarding the development of new sustainable business opportunities, the desire to contribute to reducing pollution and reversing climate change stands out as a motivation for producers and / or entrepreneurs. Ruelas, et al (2014) and Koellner, et al (2016) point 
out in their investigations the importance of the conviction of the owner of the company to enter into new practices that position it within the green market.

\subsection{Renewable energy}

Studies on the use of renewables energies show an increasingly more thermal dependent region (in particular gas), which is possible to show in the portfolio and new investments in the large countries of South America. The analyzed simulations show that although it is more efficient to promote renewable generation, it is only possible through subsidies and price regulation instead of fiscal policies, contrary to what is promoted in the legislations (Arango \& Larsen, 2010). Uncertainty in final energy prices once renewable energies are in place, high investment prices, long periods of capital recovery, and low competition for trade are alienating the private sector, and only the government or public enterprises can take the risk of these investments.

Regarding the contribution to sustainability, Colombia is a country with low greenhouse gas (GHG) emissions compared to other countries in the region, due to its low energy consumption and its high clean electricity production (hydropower represents $76 \%$ of the total of energy generation); but sustained economic growth, high incomes and the stability of the country are expected to lead to increased demand for fossil fuels (Calderón, Alvarez, Loboguerrero, Arango, Calvin, Kober \& Fisher-Vanden, 2016). According to interviews carried out by Bendiciones and Mendoza (2010) to 17 players in the value chain of palm oil, the government has implemented strategies for the development of specific subsectors of biomass in order to attract international investment, which in turn contribute to stable income and employment in vulnerable communities in the country that benefit from their production. In this sense, the government and the different actors have achieved integration from the social and economic point of view of sustainability.

Regarding the use of renewable energies, Mexico stands out for its high wind potential, which has allowed the development of generating plants mainly in the region of Oaxaca and Veracruz. As Hernández, et al (2012) points out utilizing wind resource as a substitute for some thermo plants in the state results in a savings of almost 10.000 tonnes of fuel per year, in addition to a significant reduction in CO2 emissions. However, dependence on fossil fuels is still very high (more than $50 \%$ of the electricity generated in the country), a situation that is aggravated by the existence of high enough oil reserves to avoid directing electricity generation (Silva, et al, 2012).

There are still significant challenges in efficiently transitioning into implementing sustainable energy. The research found on the development of renewable energy was concentrated in biofuels, where this trend can be exemplified by the cases presented by Balderrama, et al (2011) and Aguilar, et al (2011). They studied the production of secondgeneration biofuels, which utilizes waste material as by-products of another production process, such as the timber residues of a sawmill and biogas generated in a landfill; in both cases it is concluded that although the trend in the development of biofuels and biogas is the utilization of waste, there are high variations in the chemical composition that prevent the optimal use of resources. On the contrary, production can be considered inefficient and unable to establish these productive processes at the industrial level (Faba, Diaz \& Ordonez, 2014). 


\section{Conclusions and Implications}

This approach to the current state of Colombia and Mexico on sustainable development in the manufacturing sector is a contribution to building a platform for future strategies to achieve a sustainable industry. At the global level, the conditions under which manufacturing operates have changed. Increased competition in the productive sector, depletion of natural resources and growing social and political pressures aimed at transforming the productive system make it necessary establish longterm strategies where its activity responds both to internal needs (sales and production) and to the protection and efficient use of natural resources. However, the documentary review has revealed that the actions undertaken so far will not necessarily allow the commitments assumed at international level with the Sustainable Development Goals in relation to the industry to be reached.

In regards to the development of green markets in Colombia, the final purposes of supply and demand are not aligned. The companies undertake green strategies for the purpose of carrying out environmental responsibility activities, as well as to penetrate international markets. From the consumer's point of view it is important in order to achieve a "combination of perceived personal benefits, decreased perceived risk and uncertainty, a sense of control over costs, and a decomposition and reconstruction of deeply embedded cultural values and practices" (Carrete, et al, 2012, p. 477). Besides, in emerging economies, there is a lack of knowledge and education about environmental issues, where companies and media have a great responsability. Similarly in Mexico, the limited development of the green market responds to the low assimilation of a sustainable culture, the private initiative has not made sufficient efforts to modify its structure towards a sustainable production, and the organizations with greater achievements in this field show a tendency to use the concept as a competitive strategy. At the same time, the local consumer has not been interested in demanding greater responsibility from its suppliers.

On the other hand, it can be seen that the research centers are contributing to the analysis and development of new materials and technologies for the generation of energy and for their use as substitutes for raw materials. However, the scope of this work will be limited as long as there are no mechanisms that allow adaptation to the discoveries to the industrial structures. In this sense, it is necessary to tie the environmental and social interests with the economic aspect. In this regard, it can be pointed out that this dilemma reveals the difficulty faced by developing countries in entering into projects whose principles have not been assimilated or appropriated by the region. In the light of a more detailed review, it can be observed that they are not properly sustainable since they do not embrace the social, environmental and economic dimensions in an integrated way. As long as this situation continues, it will be difficult to take advantage of scientific and technological advances, since from its origin do not take into account the economic dimension so necessary to boost the development of each country from one of the most dynamic sector, the industrial one. 


\section{References}

Aguilar-Virgen, Q., Taboada-Gonzalez, P., \& Ojeda-Betntez, S. (2011). Potential production of electricity from biogas generated in a sanitary landfill. Ingenieria e Investigacion, 31(3), 56-65. DOI: 10.15446 / ing.investig

ANDI. (2015). Estrategia para una nueva industrialización (pp. 1-161).

Arredondo Trapero, F. G., De Lozada, Verónica del Carmen Maldonado, \& García, Jorge de la Garza. (2011). El consumidor ante la responsabilidad social corporativa. actitudes según edad y género. Cuadernos De Administración, 24(43), 285-305.

Arango, S. \& Larsen, E. R. (2010). The environmental paradox in generation: How South America is gradually becoming more dependent on thermal generation. Renewable and Sustainable Energy Reviews, 14(9), 2956-2965. doi:10.1016/j.rser.2010.07.049

Balderrama-Castaneda, S., Lujan-Alvarez, C., Lewis, D. K., Ortega-Gutierrez, J. A., de Jong, B. H. J., \& Najera-Ruiz, T. (2011). Factibilidad de generacion de electricidad mediante gasificacion de residuos de aserradero en el norte de mexico. Madera Y Bosques, 17(2), 67-84.

Banco de la República. (2015a). Informe de la Junta Directiva al Congreso de la República, XXXIII, 1-117. Retrieved from

http://www.banrep.gov.co/sites/default/files/publicaciones/archivos/ijd_jul_2015.pdf

Bernal, SA, Mejía de Gutiérrez, R., y Rodríguez, ED (2013). Materiales alcalinos activado: cementación de un futuro sostenible. Ingeniería y competitividad, 15 (2), 211-223.

Bendiciones, FAA, y Mendoza, A. (2010). La construcción de aceite de palma sostenible: cómo los actores definen la sostenibilidad. Journal of Cleaner Production , 18 (16-17), 1686-1695. doi: 10.1016 / j.jclepro.2010.07.003

Calderón, S., Alvarez, AC, Loboguerrero, AM, Arango, S., Calvin, K., Kober, T., ... y Fisher-Vanden, K. (2016). El logro de reducciones de CO 2 en Colombia: efectos de los impuestos sobre el carbono y los objetivos de reducción. Economía de la energía , 56 , 575-586. doi:10.1016/j.eneco.2015.05.010

Carrete, L., Castaño, R., Felix, R., Centeno, E., \& González, E. (2012). Green consumer behavior in an emerging economy: confusion, credibility, and compatibility. Journal of consumer marketing, 29(7), 470-481. doi:10.1108/07363761211274983

Castañeda, J. S. (2014). Contextualización y enfoques en el estudio de comportamientos proambientales o ecológicos con miras a la perfilación del consumidor verde. Suma de Negocios, 5(10), 34-39. doi: 10.1016/S2215-910X(14)70007-2

Chacón Páez, I., Pinzón Vargas, A. C., Ortegón Cortázar, L., \& Rojas Berrio, S. P. (2016). Scope and management of carbon footprint as a driving force of branding for companies implementing these environmental practices in Colombia. Estudios Gerenciales, 32(140), 278-289. doi: 10.1016/j.estger.2016.08.004

Crowder, D. W., Reganold, J. P. (2015). Financial competitiveness of organic agriculture on a global scale. Proc. Natl. Acad. Sci. Actas de la Academia Nacional de Ciencias , 112 (24), 7611-7616. doi: 10.1073/pnas.1423674112.

De la Paz-Perez Olvera, Carmen, \& Davalos-Sotelo, R. (2016). Anatomia de la madera de seis especies de pinus del estado de durango, mexico. Madera Y Bosques, 22(3), 113.

Faba, L., Diaz, E., \& Ordonez, S. (2014). Transformacion de biomasa en biocombustibles de segunda generacion. Madera Y Bosques, 20(3), 11.

Fuentes-Talavera, F. J., Silva-Guzman, J. A., Rodriguez-Anda, R., Lomeli-Ramirez, M. G., Sanjuan-Duenas, R., \& Richter, H. G. (2011). Propiedades de resistencia y durabilidad natural de la madera de ramas de aguacate. Madera Y Bosques, 17(1), 37-48.

Gómez, J. M. (2016). Análisis de la variación de la eficiencia en la producción de biocombustibles en américa Latina. Estudios Gerenciales, 32(139), 120. doi:10.1016/j.estger.2016.01.001

Gómez, M. C., \& Berlanga, G. P. (2013). Restaurantes toks: Estrategias de responsabilidad social. Innovar, 23(49), 141.

González, C. (2011). Empresas Socialmente Responsables y mercado verde internacional. Revista Economía Informa, núm. 366, enero-febrero, 2011. 
Hernández, H. Jorge I. (coord.) (2004) Nuevas Energías Renovables. Una alternativa energética sustentable para México, análisis y prospectiva. Instituto de Investigaciones Legislativas del Senado de la República. 10-14; 125-145.

INEGI. (2015). Información Oportuna sobre la actividad industrial en México durante enero de 2015. Instituto Nacional de Estadística y Geografía. México, Aguascalientes. 2015

Jaramillo, E. B., Muñoz, L., Ossa, A., \& Romo, M. P. (2014). Comportamiento mecánico del polietileno tereftalato (PET) y sus aplicaciones geotécnicas/Mechanical behavior of polyethylene terephthalate (PET) and geotechnical applications. Revista Facultad De Ingeniería Universidad De Antioquia, (70), 207.

Koellner, E. C., Hidalgo, J. F. O., \& Hidalgo, M. G. A. (2016). La Responsabilidad Social Empresarial de las Pymes del Estado de Guanajuato, México. Recherches en Sciences de Gestion, (3), 77-100. doi: 10.3917/resg.114.0077

Mantilla, C. L., Garcia Tamara, L. P., \& Oviedo Zumaque, L. E. (2010). Medio de cultivo utilizando residuos-solidos para el crecimiento de una bacteria nativa con potencial biofertilizante. Revista Colombiana De Biotecnologia, 12(1), 103-112.

Méndez-Beltrán, J. A., \& Peralta-Borray, D. A. (2014). Reflexiones respecto a la responsabilidad social empresarial y la creación de valor económico desde la perspectiva de los proveedores. Cuadernos De Contabilidad, 15(38). doi: 10.11144/Javeriana.cc15-38.rrrs

Navarrete Baez, F. E. (2015). Las practicas de desarrollo sustentable: Un acercamiento descriptivo a las pequenas empresas de guadalajara, mexico. Cuadernos De Administracion,31(53), 48.

OCDE. (2009). Sustainable Manufacturing and Eco-Innovation. Framework, Practices and Measurement. Synthesis report.

Perales, B. (2012). El universo de las energías renovables. Capítulo 4 Repercusiones económicas y medioambientales. Barcelona, España. Editorial Macombo.

Quintanar-Isaias, A., Jacobo-Villa, M. A., Lopez-Binnquist, C., Flores-Hernandez, N., Jaramillo-Perez, A. T., \& de la Paz Perez-Olvera, Carmen. (2012). La madera de trema micrantha blume de Veracruz, Mexico. Madera Y Bosques, 18(2), 73.

Ruelas-Monjardin, L. C., Nava-Tablada, M. E., Cervantes, J., \& Barradas, V. L. (2014). Importancia ambiental de los agroecosistemas cafetaleros bajo sombra en la zona central montanosa del estado de veracruz, mexico. Madera Y Bosques, 20(3), 27.

Saavedra Garcia, M. L. (2011). La responsabilidad social empresarial y las finanzas. Revista Cuadernos De Administracion, 27(46), 39.

Santos Lopez, F. M., \& Santos De la Cruz, Eulogio. (2010). Aplicacion de un modelo para la implementacion de logistica inversa en la etapa productiva. Industrial Data, 13(1), 32.

Silva, F. B., Díaz, A. L., Mínguez, S. Z., \& Arribas, D. R. (2012). Modelos de diversificación energética en Iberoamérica. Observatorio Medioambiental, 15, 103. doi:10.5209/rev_OBMD.2012.v15.40333

Subgerencia Cultural del Banco de la República. (2015). Mercados verdes. Recuperado de: http://www.banrepcultural.org/blaavirtual/ayudadetareas/ciencias/mercados_verdes

UNESCO. Enseñanza y aprendizaje para un futuro sostenible. UNESCO Recuperado de: http://www.unescoetxea.org/ext/futuros/es/theme_b/uncofrm_b.htm

Vargas-Radillo, J. J., Salazar-Ríos, E., Barrientos-Ramírez, L., Pérez-Centeno, A., Rentería-Urquiza, M., Rodríguez-Rivas, A.,... Rutiaga-Quiñones, J. (2015). Pasta blanqueada y azúcares fermentables a partir de médula de bagazo de caña. Madera Y Bosques, 21(2), 117-130.

Villegas, M. (2013). "Marketing ecológico: propuesta para mejorar la sustentabilidad de cuatro pymes de los sectores industrial, comercio y servicios de la Ciudad Xalapa, Veracruz". Instituto de Investigaciones y Estudios Superiores de las Ciencias Administrativas. Xalapa, Veracruz.

West, J., y Schandl, H. (2013). Material use and material efficiency in Latin America and the Caribbean. Ecological Economics, 94, 19-27. doi:10.1016/j.ecolecon.2013.06.015 